\title{
Toxicity of the Herbicide Atrazine: Effects on Lipid Peroxidation and Activities of Antioxidant Enzymes in the Freshwater Fish Channa Punctatus (Bloch)
}

\section{Christopher Ddidigwu Nwani ${ }^{1,2, *}$, Wazir Singh Lakra ${ }^{2}$, Naresh Sahebrao Nagpure ${ }^{2}$,} Ravindra Kumar ${ }^{2}$, Basdeo Kushwaha ${ }^{2}$ and Satish Kumar Srivastava ${ }^{2}$

${ }^{1}$ Department of Applied Biology, Ebonyi State University, PMB 053, Abakaliki, Ebonyi State, Nigeria

2 National Bureau of Fish Genetic Resources (Indian Council of Agricultural Research), Canal Ring Road, PO- Dilkusha Lucknow 226002 (UP), India; E-Mails: lakraws@ @otmail.com (W.S.L.); nagpurens@yahoo.com (N.S.N.); ravindrakumar@scientist.com (R.K.); basdeokushwaha@yahoo.co.in (B.K.); satishsrivastava@mail.com (S.K.S.)

* Author to whom correspondence should be addressed; E-Mail: didigwunwani@yahoo.com.

\begin{abstract}
The present study was undertaken to evaluate the toxicity and effects of a commercial formulation of the herbicide atrazine (Rasayanzine) on lipid peroxidation and antioxidant enzyme system in the freshwater air breathing fish Channa punctatus. The 12, 24, 48, 72 and $96 \mathrm{~h} \mathrm{LC}_{50}$ of atrazine, calculated by probit analysis, were determined to be $77.091,64.053,49.100,44.412$ and $42.381 \mathrm{mg} \cdot \mathrm{L}^{-1}$, respectively, in a semi static system with significant difference $(\mathrm{p}<0.05)$ in $\mathrm{LC}_{10-90}$ values obtained for different times of exposure. In addition to concentration and time dependent decrease in mortality rate, stress signs in the form of behavioral changes were also observed in response to the test chemical. In fish exposed for 15 days to different sublethal concentrations of the herbicide $\left(1 / 4 \mathrm{LC}_{50}=\sim 10.600 \mathrm{mg} \cdot \mathrm{L}^{-1}, 1 / 8 \mathrm{LC}_{50}=\sim 5.300 \mathrm{mg} \cdot \mathrm{L}^{-1}\right.$ and $1 / 10 \mathrm{LC}_{50}=\sim 4.238 \mathrm{mg} \cdot \mathrm{L}^{-1}$ ) induction of oxidative stress in the liver was evidence by increased lipid peroxidation levels. The antioxidants superoxide dismutase (SOD), catalase (CAT) and glutathione reductase (GR) responded positively in a concentration dependent pattern, thus, suggesting the use of these antioxidants as potential biomarkers of toxicity associated with contaminations exposure in freshwater fishes.
\end{abstract}


Keywords: atrazine; toxicity; C. punctatus; oxidative stress; environmental pollution; $\mathrm{LC}_{10-90}$

\section{Introduction}

The use of herbicides to control weeds has been recognized as a part of agricultural practices throughout the world. Unfortunately, the indiscriminate use of these herbicides to improve agricultural production and yield may have impacts on non-target organisms, especially aquatic life forms and their environment. Atrazine (2-chloro-4-ethylamino-6-isopropylamino-s-triazine) is one of the most commonly used herbicides found in the rural environments. It is extensively used on corn, sorghum, sugarcane, pineapples, and to some extent on landscape vegetation. Rated as moderately toxic to aquatic species, atrazine is mobile in the environment and is among the most detected pesticides in streams, rivers, ponds, reservoirs and ground waters [1-3]. It has a hydrolysis half-life of 30 days and relatively high water solubility $\left(32 \mathrm{mg} \cdot \mathrm{L}^{-1}\right)$, which aids in its infiltration into ground water [4]. Atrazine concentrations of $20 \mu \mathrm{g} \cdot \mathrm{L}^{-1}$ have been commonly detected in surface water runoff, while concentrations as high as $700 \mu \mathrm{g} \cdot \mathrm{L}^{-1}$ have been reported [5-7]. Due to the low persistence of atrazine herbicide, repeated applications are practiced for the control of weeds in agricultural fields, and as a result, large quantities of the herbicide find their ways into water bodies. The mode of action of atrazine is blocking electron transport in photosystem 11 leading to chlorophyll destruction and blocking photosynthesis. When atrazine was first released for agricultural use, it was thought that since photosynthesis is limited to plants, animals would be immune to any effects of atrazine. It was soon suspected that atrazine might have non-target action in animals including genotoxic [8], clastogenic [9] and biochemical effects [10]. The indiscriminate use of this herbicide, careless handling, accidental spillage or discharge of untreated effluents into natural water ways have harmful effects on the fish populations and other aquatic organisms and may contribute to long term effects in the environment. Sublethal effects with biochemical and histopathological alteration of fish tissues may occur with long term exposure to levels of less than $2 \mathrm{mg} \cdot \mathrm{L}^{-1}$ of atrazine [11].

Fish can serve as bio-indicators of environmental pollution and can play significant roles in assessing potential risk associated with contamination in aquatic environment since they are directly exposed to chemicals resulting from agricultural production via surface run-off or indirectly through food chain of ecosystem [12]. Fish are endowed with defensive mechanisms to counteract the impact of reactive oxygen species (ROS) resulting from metabolism of various chemicals or xenobiotics. Oxidative stress develops when there is an imbalance between pro-oxidants and antioxidants ratio, leading to the generation of ROS. Environmental contaminants such as herbicides, heavy metals and insecticides are known to modulate antioxidant defensive systems and to cause oxidative damage in aquatic organisms by ROS production [13-16]. ROS such as hydrogen peroxide $\left(\mathrm{H}_{2} \mathrm{O}_{2}\right)$, superoxide anion $\mathrm{O}_{2}{ }^{-}$and hydroxyl radical $(\mathrm{OH})$ at supranormal levels can react with biological macromolecules potentially leading to enzyme inactivation, lipid peroxidation (LPO), DNA damage and even cell death $[17,18]$ but at low concentrations their effects are less pronounced. 
Several ecotoxicological characteristics of $C$. punctatus such as wide distribution in the freshwater environment, availability throughout the year, easy acclimatization to laboratory conditions and commercial importance make this species an excellent test species for toxicity and biochemical studies [19]. There have been studies on toxicities of atrazine-based herbicides; however meager information is available about their toxicity and effects on fish and aquatic organisms especially on sub-chronic exposure. Determination of the toxicity is essential for determining sensitivity of the animals to the toxicants and also useful for evaluating the degree of damage to the target organs and the consequent physiological, biochemical and behavioral disorders. Thus, to supplement risk assessment studies of these herbicides, it is important to obtain information on their toxicity and effects on some local species like $C$. punctatus.

The aim of the present study was to assess the toxicity of a commercial formulation of the herbicide atrazine (Rasayanzine) and the impact on some biochemical indices in C. punctatus. The information obtained may be useful for management and monitoring of atrazine (Rasayanzine) contamination in the environment.

\section{Materials and Methods}

\subsection{Experimental Fish Specimens and Chemicals}

Freshwater air-breathing fish C. punctatus (Bloch; Family: Channidae, Order: Perciformes) were procured from local sources. The specimens had an average weight and length of $14.40 \pm 1.00 \mathrm{~g}$ and $10.42 \pm 1.02 \mathrm{~cm}$, respectively. Fish specimens were subjected to a prophylactic treatment by bathing twice in $0.05 \%$ potassium permanganate $\left(\mathrm{KMnO}_{4}\right)$ for two min. to avoid any dermal infections. The fishes were then acclimatized for two weeks under laboratory conditions in semi-static systems. They were fed boiled eggs, minced goat liver and poultry waste materials. The fecal matter and other waste materials were siphoned off daily to reduce ammonia content in water. For the present study commercial formulations of atrazine (50\% WP) with the trade name "Rasayanzine", manufactured by Krishi Rasayan Exports Ltd (India) was purchased from the market.

\subsection{Determination of Sub-Lethal Concentrations}

Acute toxicity bioassays to determine the $96 \mathrm{~h} \mathrm{LC}_{50}$ value of atrazine was conducted in a semi-static laboratory system according to the OECD guideline No 203 [20]. Atrazine was dissolved in filtered distilled water and added to the aquarium following the method of Pluta [21]. The water with herbicide was changed after every $24 \mathrm{~h}$ by adding the fresh atrazine solution in order to counterbalance decreasing herbicide concentrations because of its hydrolysis in water. The experiment was conducted in glass aquaria $(60 \times 30 \times 30 \mathrm{~cm})$, containing $40 \mathrm{~L}$ of dechlorinated and gentle aerated tap water. A set of 10 fish specimens were randomly exposed to each of the nominal atrazine concentrations $\left(25.0,32.0,39.0,46.0,53.0\right.$ and $\left.60.0 \mathrm{mg} \cdot \mathrm{L}^{-1}\right)$ and a control $\left(0.00 \mathrm{mg} \cdot \mathrm{L}^{-1}\right)$ and the experiment was set in triplicate to obtain the $\mathrm{LC}_{50}$ values of the test herbicide for the species. The $\mathrm{LC}_{50}$ value of atrazine for $C$. punctatus was determined as $42.381 \mathrm{mg} \cdot \mathrm{L}^{-1}$ following the probit analysis method as described by Finney [22]. Based on the $96 \mathrm{hLC}_{50}$ values, the fish were then exposed for 15 days to three sub-lethal concentrations of the herbicide $\left(1 / 4 \mathrm{LC}_{50}=\sim 10.600 \mathrm{mg} \cdot \mathrm{L}^{-1}, 1 / 8 \mathrm{LC}_{50}=\sim 5.300\right.$ 
$\mathrm{mg} \cdot \mathrm{L}^{-1}$ and $1 / 10 \mathrm{LC}_{50}=\sim 4.238 \mathrm{mg} \cdot \mathrm{L}^{-1}$ ) and used for the enzyme assays. A set of 10 fish were also simultaneously maintained in tap water $\left(0.00 \mathrm{mg} \cdot \mathrm{L}^{-1}\right)$ as the control. No mortalities occurred following the exposure to the three sublethal concentrations of the herbicide during the experiment.

\subsection{Tissue Sampling}

The fish specimens were exposed to the three aforementioned test concentrations of atrazine along with the control and the experiments continued for 15 days. At the end of every 1, 5, 7, 10 and 15 days five fishes were sacrificed by cervical decapitation. The liver was dissected out carefully, washed in ice-cold $1.15 \% \mathrm{KCl}$ solution, blotted and weighed. They were then homogenized in homogenizing buffer (50mM Tris-HCl mixed with $1.15 \mathrm{KCL}$ and $\mathrm{pH}$ adjusted to 7.4) using a motor-driven Teflon Potter-Elvejhem homogenizer. The resulting homogenate was centrifuged at 10,000 $\mathrm{g}$ for $20 \mathrm{~min}$ in a refrigerated centrifuge at $4{ }^{\circ} \mathrm{C}$. The clear supernatants collected were used for protein estimation and assaying the activity of enzymes.

\subsection{Biochemical Assays}

Lipid peroxidation was assayed by measuring malondialdehyde (MDA) formation as described by Sharma and Krishnamurthy [23]. Briefly, $1.0 \mathrm{~mL}$ of homogenate prepared in $\mathrm{KCl}$ solution was incubated at $37{ }^{\circ} \mathrm{C}$ for $30 \mathrm{~min}$. Proteins were precipitated by adding $1 \mathrm{~mL}$ of $10 \%$ trichloroacetic acid (TCA) and then centrifuged at 2,000 $\mathrm{g}$ for $15 \mathrm{~min}$. One $\mathrm{mL}$ of supernatant was taken as an aliquot in separate tube to which $1 \mathrm{~mL}$ of thiobarbituric acid reacting substances (TBA) solution was added. The tubes were kept in boiling water bath for $10 \mathrm{~min}$. After cooling the tubes, the optical density was read at $535 \mathrm{~nm}$. Superoxide dismutase (SOD) activity was determined by measuring the inhibition of autoxidation of adrenaline at $\mathrm{pH} 10.2$ at $30^{\circ} \mathrm{C}$ as described by Misra and Fridovich [24]. Activity of catalase (CAT) was determined according the procedure of Clairborne [25] by following the absorbance of $\mathrm{H}_{2} \mathrm{O}_{2}$ at $240 \mathrm{~nm}$, pH 7.0 and $25{ }^{\circ} \mathrm{C}$. Activity of glutathione reductase (GR) was measured according to the method of Massey and Williams [26]. All assays were run in the triplicate. The protein content of the various fractions was estimated by the Folin-Phenol reaction method as described by Lowry et al. [27].

\subsection{Data Analysis}

The data obtained were statistically analyzed by statistical package SPSS (version 16). The data were subjected to one way ANOVA and Duncan's multiple range test was used to determine the significant difference between the means at 5\% probability level. The safe level estimates of the herbicides were drawn based on Sprague [28], CWQC [29], NAS/NAE [30], IJC [31], CCREM [32] and Hart et al. [33]. 


\section{Results}

\subsection{Physico-Chemical Parameters of the Test Water}

The physico-chemical characteristics of the test water are presented in (Table 1). The water temperature varied from 24.20 to $25.40{ }^{\circ} \mathrm{C}$ and the $\mathrm{pH}$ ranged from 7.4 to 7.9. The dissolved oxygen concentration ranged from 6.7 to $7.8 \mathrm{mg} \cdot \mathrm{L}^{-1}$; conductivity values ranged from 260 to $300 \mu \mathrm{M} \cdot \mathrm{cm}^{-1}$ while total hardness varied from $200-230 \mathrm{mg} \cdot \mathrm{L}^{-1}$ during the experimental period.

Table 1. Physico-chemical properties of the test water.

\begin{tabular}{cccc}
\hline Characteristics & Unit & Mean & Range \\
\hline Air temperature & ${ }^{\circ} \mathrm{C}$ & 26.20 & $25.6-26.6$ \\
Water temperature & ${ }^{\circ} \mathrm{C}$ & 24.40 & $24.2-25.4$ \\
$\mathrm{pH}$ & - & 7.6 & $7.4-7.9$ \\
Dissolved oxygen & $\mathrm{mg} \cdot \mathrm{L}^{-1}$ & 6.8 & $6.7-7.8$ \\
Conductivity & $\mu \mathrm{Mcm}^{-1}$ & 282 & $260-300$ \\
Total hardness & $\mathrm{mg} \cdot \mathrm{L}^{-1}$ & 220 & $200-230$ \\
\hline
\end{tabular}

\subsection{Toxic Stress and Poisoning Symptoms in Fish}

Fish subjected to different concentrations of atrazine herbicide displayed uncoordinated behavior. At the initial exposure, fish were alert, stopped swimming and remained static in position in response to the sudden changes in the surrounding environment. After some time they tried to avoid the toxic water with fast swimming and jumping. Faster opercula activity was observed as surfacing and gulping for air. In tanks with higher concentrations of test herbicide, the fish swam erratically with vigorous jerks of the body. Their fins became hard and stretched due to stretching of body muscles. They secreted copious amounts of mucus from whole body continuously and soon a thick layer of mucus was found deposited in the buccal cavity and gills. Body pigmentation was decreased. Ultimately fish lost their balance, consciousness, engage in rolling movement and became exhausted and lethargic. Lastly, they remained in vertical position for a few minutes with anterior side or terminal mouth up near the surface of the water, trying to gulp air and tail in a downward direction. Soon they settled at the bottom of the tank, and after some time their bellies turned upward and the fish died.

\subsection{Median Lethal Concentration $\left(L C_{50}\right)$ and Application Factor}

Median lethal concentration $\left(\mathrm{LC}_{50}\right)$ is the most widely accepted basis for acute toxicity test and it is the concentration of a test chemical which kills $50 \%$ of the test organisms after a particular length of exposure, usually $96 \mathrm{~h}$. Generally in toxicity tests, death is a decisive criterion because it is easy to determine and has obvious biological and ecological significance. The $\mathrm{LC}_{50}$ values (with 95\% confidence limits) of different concentrations of atrazine (Table 2) were found to be 77.091, 64.053, 49.100, 44.412 and $44.381 \mathrm{mg} \cdot \mathrm{L}^{-1}$ for $12,24,48,72$ and $96 \mathrm{~h} \mathrm{LC}_{50}$, respectively following Finney's [22] method and using SPSS (version 16). A dose dependent increase and time dependent decrease were observed in mortality rate, such that as the exposure time increases from 12 to $96 \mathrm{~h}$, the median concentration was reduced. There were significant differences $(\mathrm{p}<0.05)$ in $\mathrm{LC}_{10-90}$ values 
obtained for different times of exposures. It was observed that as the concentration of the herbicide increased fish mortality also increased that indicates a direct proportional relationship between mortality and concentration of atrazine herbicide. No mortality was observed in the control during the experimental period. There were variations in safe level estimated by different methods at $96 \mathrm{~h}$ of exposure of the fish as presented in (Table 3).

Table 2. Lethal concentrations $\left(\mathrm{LC}_{10-90}\right)$ of atrazine depending on exposure time $(12-96 \mathrm{~h})$ for $C$. punctatus.

\begin{tabular}{|c|c|c|c|c|c|}
\hline \multirow[t]{2}{*}{ Point } & \multicolumn{5}{|c|}{$\begin{array}{l}\text { Concentrations }\left(\mathrm{mg} \cdot \mathrm{L}^{-1}\right) \text { at various exposure times. } \\
(95 \% \text { confidence intervals })\end{array}$} \\
\hline & $12 \mathrm{~h}$ & $24 \mathrm{~h}$ & $48 \mathrm{~h}$ & $72 \mathrm{~h}$ & $96 \mathrm{~h}$ \\
\hline \multirow[t]{2}{*}{$\mathbf{L C}_{10}$} & $50.501^{\mathrm{a}}$ & $43.042^{\mathrm{b}}$ & $37.383^{\mathrm{c}}$ & $34.664^{\mathrm{d}}$ & $33.192^{d}$ \\
\hline & (43.110-56.190) & (36.661-46.872) & $(33.422-40.111)$ & $(31.322-37.061)$ & $(29.920-35.542)$ \\
\hline \multirow[t]{2}{*}{$\mathbf{L C}_{20}$} & $58.502^{\mathrm{a}}$ & $49.331^{\mathrm{b}}$ & $41.054^{\mathrm{c}}$ & $37.742^{\mathrm{d}}$ & $36.093^{\mathrm{d}}$ \\
\hline & (52.680-77.012) & (442.92-53.272) & $(37.781-43.473)$ & (34.890-39.901) & $(33.292-38.201)$ \\
\hline \multirow[t]{2}{*}{$\mathbf{L C}_{30}$} & $65.042^{\mathrm{a}}$ & $54.443^{\mathrm{b}}$ & $43.911^{\mathrm{c}}$ & $40.133^{\mathrm{d}}$ & $38.343^{\mathrm{d}}$ \\
\hline & $(57.474-101.282)$ & $(50.263-61.351)$ & (41.111-46.253) & $(37.622-42.182)$ & $(35.872-40.344)$ \\
\hline \multirow[t]{2}{*}{$\mathbf{L C}_{40}$} & $71.203^{\mathrm{a}}$ & $59.210^{\mathrm{b}}$ & $46.522^{\mathrm{c}}$ & $42.282^{\mathrm{d}}$ & $40.382^{\mathrm{d}}$ \\
\hline & $(61.291-129.286)$ & (54.284-70.050) & (43.993-48.982) & (40.015-44.350) & (38.114-42.306) \\
\hline \multirow[t]{2}{*}{$\mathbf{L C}_{50}$} & $77.091^{\mathrm{a}}$ & $64.053^{\mathrm{b}}$ & $49.100^{c}$ & $44.412^{\mathrm{d}}$ & $42.381^{\mathrm{d}}$ \\
\hline & $(64.816-162.927)$ & (57.806-79.92) & (46.623-51.914) & (42.252-46.623) & (40.218-44.406) \\
\hline \multirow[t]{2}{*}{$\mathbf{L C}_{60}$} & $84.342^{\mathrm{a}}$ & $69.293^{\mathrm{b}}$ & $51.814^{\mathrm{c}}$ & $46.642^{\mathrm{d}}$ & $44.471^{\mathrm{d}}$ \\
\hline & $(68.503-205.719)$ & (61.425-91.522) & (49.210-55.324) & (44.417-49.109) & $(42.420-46.822)$ \\
\hline \multirow[t]{2}{*}{$\mathbf{L C}_{70}$} & $92.343^{\mathrm{a}}$ & $75.372^{\mathrm{b}}$ & $54.892^{\mathrm{c}}$ & $49.152^{\mathrm{d}}$ & $46.834^{\mathrm{d}}$ \\
\hline & $(72.620-264.422)$ & $(65.319-106.103)$ & (51.890-59.247) & (46.801-52.228) & (44.632-49.607) \\
\hline \multirow[t]{2}{*}{$\mathrm{LC}_{80}$} & $102.661^{\mathrm{a}}$ & $83.164^{\mathrm{b}}$ & $58.723^{\mathrm{c}}$ & $52.260^{\mathrm{d}}$ & $49.754^{\mathrm{d}}$ \\
\hline & $(77.612-354.807)$ & $(70.221-126.014)$ & $(55.032-64.911)$ & $(49.501-56.331)$ & $(47.223-53.412)$ \\
\hline \multirow[t]{2}{*}{$\mathrm{LC}_{90}$} & $118.932^{\mathrm{a}}$ & $95.321^{\mathrm{b}}$ & $64.483^{\mathrm{c}}$ & $56.902^{\mathrm{d}}$ & $54.113^{\mathrm{d}}$ \\
\hline & $(85.017-534.116)$ & $(77.411-160.716)$ & $(59.511-73.515)$ & $(53.322-62.722)$ & $(50.804-59.332)$ \\
\hline
\end{tabular}

Note: Lethal concentration values in rows with different letters significantly differ at $p<0.05$.

Table 3. Estimate of safe level of atrazine at $96 \mathrm{~h}$ exposure time in C. punctatus.

\begin{tabular}{clcc}
\hline $\mathbf{9 6} \mathbf{~ h ~ L C} \mathbf{~}_{\mathbf{5 0}}\left(\mathbf{m g} \cdot \mathbf{L}^{-\mathbf{1}}\right)$ & Method & AF & Safe level $\left(\mathbf{m g} \cdot \mathbf{L}^{-\mathbf{1}}\right)$ \\
\hline 42.38 & Hart et al. [33]* & - & 8.657 \\
& Sprague [28] & 0.1 & 4.240 \\
& CWQC [29] & 0.01 & 0.424 \\
& NAS/NAE [30] & $0.1-0.00001$ & $4.24-4.24 \times 10^{-4}$ \\
& CCREM [32] & 0.05 & 2.129 \\
& IJC [31] & 5\% of 96hLC & 2.129 \\
\hline
\end{tabular}

$* \mathrm{C}=48 \mathrm{~h} \mathrm{LC}_{50} \times 0.03 / \mathrm{S}^{2}$, where $\mathrm{C}$ is the presumable harmless concentration and $\mathrm{S}=24 \mathrm{~h} \mathrm{LC}_{50} / 48 \mathrm{~h} \mathrm{LC}_{50}$ 


\subsection{Oxidative Stress Marker}

Lipid peroxidation determined by the formation of TBARS is one of the commonly used markers of oxidative stress. The effects of different concentrations of atrazine on TBARS formation in the liver of C. punctatus are presented in Table 4. A significant effect of both concentrations and duration of exposure $(\mathrm{p}<0.05)$ was observed in the specimen exposed to atrazine. The lowest TBARS formation was observed on the first day of exposure to $4.238 \mathrm{mg} \cdot \mathrm{L}^{-1}$ of herbicide and there was gradual non linear increase in TBARS formation in the liver tissue with the progression of the experiment, with the highest TBARS formation on the day 15. At the highest sublethal concentration of atrazine $\left(10.600 \mathrm{mg} \cdot \mathrm{L}^{-1}\right)$, TBARS formation increased by a factor of 1.450 on day 1 and by 4.431 on day 15 , when compared with the control.

Table 4. Formation of thiobarbituric acid reactive substances (TBARS) (nmol/mg protein) in liver of $C$. punctatus exposed to sublethal doses of atrazine for 1-15 days.

\begin{tabular}{cccccc}
\hline${\text { Conc. } \mathbf{~ m g} \cdot \mathbf{L}^{\mathbf{- 1}}}^{\mathbf{1}}$ & $\mathbf{5}$ & $\mathbf{5}$ & $\mathbf{1 0}$ & $\mathbf{1 5}$ \\
\hline 00 & $1.011 \pm 0.06^{\mathrm{aA}}$ & $1.042 \pm 0.07^{\mathrm{aA}}$ & $1.034 \pm 0.05^{\mathrm{aA}}$ & $1.011 \pm 0.07^{\mathrm{aA}}$ & $1.002 \pm 0.01^{\mathrm{aA}}$ \\
4.238 & $1.060 \pm 0.03^{\mathrm{aA}}$ & $1.193 \pm 0.05^{\mathrm{aAB}}$ & $1.351 \pm 0.08^{\mathrm{aAB}}$ & $2.312 \pm 0.16^{\mathrm{cB}}$ & $2.881 \pm 0.10^{\mathrm{dB}}$ \\
5.300 & $1.183 \pm 0.45^{\mathrm{aA}}$ & $1.660 \pm 0.19^{\mathrm{aB}}$ & $2.334 \pm 0.16^{\mathrm{bC}}$ & $2.512 \pm 0.13^{\mathrm{bB}}$ & $3.664 \pm 0.17^{\mathrm{cC}}$ \\
10.600 & $1.472 \pm 0.43^{\mathrm{aB}}$ & $2.884 \pm 0.11^{\mathrm{bC}}$ & $3.022 \pm 0.10^{\mathrm{bD}}$ & $3.064 \pm 0.11^{\mathrm{bC}}$ & $4.431 \pm 0.33^{\mathrm{cC}}$ \\
\hline
\end{tabular}

Note: Data are presented as mean \pm SE of five fishes in each group, values with different alphabet superscript differ significantly $(\mathrm{p}<0.05)$ between durations within concentration. Values with capital alphabet superscript differ significantly $(\mathrm{p}<0.05)$ between concentrations within duration.

\subsection{Antioxidant Enzyme Activity}

The activities of the enzyme SOD in the liver of the fishes exposed to atrazine herbicide are presented in Table 5. SOD activity was significantly $(p<0.05)$ elevated in the liver at all the concentrations of atrazine in the experimental group.

Table 5. Activity of Superoxide dismutase (unit/mg protein) in the liver of C. punctatus exposed to sub-lethal doses of Atrazine for 1-15 days.

\begin{tabular}{cccccc}
\hline Conc. $\mathbf{~ m g} \cdot \mathbf{L}^{-\mathbf{1}}$ & $\mathbf{1}$ & $\mathbf{5}$ & $\mathbf{7}$ & $\mathbf{1 0}$ & $\mathbf{1 5}$ \\
\hline 00 & $17.851 \pm 0.09^{\mathrm{aA}}$ & $17.861 \pm 0.10^{\mathrm{A}}$ & $17.882 \pm 0.21^{\mathrm{A}}$ & $17.902 \pm 0.11^{\mathrm{aA}}$ & $17.952 \pm 0.32^{\mathrm{aA}}$ \\
4.238 & $19.860 \pm 0.17^{\mathrm{aB}}$ & $21.764 \pm 0.45^{\mathrm{bB}}$ & $29.961 \pm 0.26^{\mathrm{cB}}$ & $30.573 \pm 0.55^{\mathrm{B}}$ & $32.840 \pm 0.67^{\mathrm{dB}}$ \\
5.300 & $20.284 \pm 0.67^{\mathrm{aB}}$ & $23.463 \pm 0.50^{\mathrm{bB}}$ & $29.890 \pm 0.15^{\mathrm{cB}}$ & $32.571 \pm 0.50^{\mathrm{dB}}$ & $33.872 \pm 0.60^{\mathrm{dB}}$ \\
10.600 & $22.763 \pm 0.44^{\mathrm{aC}}$ & $24.274 \pm 0.65^{\mathrm{aC}}$ & $30.853 \pm 0.50^{\mathrm{bB}}$ & $34.820 \pm 0.53^{\mathrm{cC}}$ & $36.091 \pm 0.33^{\mathrm{cC}}$ \\
\hline
\end{tabular}

Note: Data are presented as mean \pm SE of five fishes in each group, values with different alphabet superscript differ significantly $(\mathrm{p}<0.05)$ between durations within concentration. Values with capital alphabet superscript differ significantly $(\mathrm{p}<0.05)$ between concentrations within duration.

SOD activity increased in concentration and time dependent pattern with percentage increase of $28 \%$ and $101 \%$ observed at the highest concentration $\left(10.600 \mathrm{mg} \cdot \mathrm{L}^{-1}\right)$ on day 1 and 15 of the herbicide exposure respectively, as compared to control. The activities of CAT follow the same pattern as SOD in the liver of $C$. punctatus exposed to atrazine but up to day 7 of exposure. CAT activity in 
the liver was significantly different from the control $(\mathrm{p}<0.05)$ and decreased from $79 \%$ on day 7 to $27 \%$ on day 15 following exposure to $10.600 \mathrm{mg} \cdot \mathrm{L}^{-1}$ of atrazine (Table 6).

Table 6. Activity of catalase (unit/mg protein) in the liver of $C$. punctatus exposed to sub-lethal doses of atrazine for 1-15 days.

\begin{tabular}{cccccc}
\hline \multirow{2}{*}{ Conc. $\mathbf{~ m g} \cdot \mathbf{L}^{-\mathbf{1}}$} & $\mathbf{5}$ & Exposure time (days) \\
\cline { 2 - 6 } & $\mathbf{1}$ & $\mathbf{5}$ & $\mathbf{7}$ & $\mathbf{1 0}$ & $\mathbf{1 5}$ \\
\hline 00 & $130.880 \pm 0.47^{\mathrm{aA}}$ & $130.910 \pm 0.15^{\mathrm{aA}}$ & $131.092 \pm 0.58^{\mathrm{aA}}$ & $131.531 \pm 0.34^{\mathrm{aA}}$ & $130.762 \pm 0.66^{\mathrm{aA}}$ \\
4.238 & $165.122 \pm 4.33^{\mathrm{aB}}$ & $172.011 \pm 4.25^{\mathrm{aB}}$ & $165.430 \pm 2.16^{\mathrm{aB}}$ & $159.640 \pm 3.12^{\mathrm{aB}}$ & $150.322 \pm 0.57^{\mathrm{bB}}$ \\
5.300 & $165.292 \pm 2.71^{\mathrm{aB}}$ & $175.604 \pm 3.44^{\mathrm{aBB}}$ & $185.630 \pm 3.22^{\mathrm{bC}}$ & $180.361 \pm 2.80^{\mathrm{bC}}$ & $156.181 \pm 3.42^{\mathrm{aB}}$ \\
10.600 & $171.981 \pm 4.30^{\mathrm{aB}}$ & $177.240 \pm 3.11^{\mathrm{abB}}$ & $235.192 \pm 3.22^{\mathrm{cD}}$ & $202.444 \pm 3.11^{\mathrm{dD}}$ & $164.282 \pm 2.33^{\mathrm{acB}}$ \\
\hline
\end{tabular}

Note: Data are presented as mean \pm SE of five fishes in each group, values with different alphabet superscript differ significantly $(\mathrm{p}<0.05)$ between durations within concentration. Values with capital alphabet superscript differ significantly $(\mathrm{p}<0.05)$ between concentrations within duration.

There was no significant increase $(\mathrm{p}>0.05)$ in GR activity in the liver of the fish exposed to sublethal concentration of the herbicide compared with the control except on day 10 and 15. GR activity increased significantly to $44 \%$ in the liver on day 10 to $73 \%$ on day 15 following exposure to $10.600 \mathrm{mg} \cdot \mathrm{L}^{-1}$ of the herbicide (Table 7 ).

Table 7. Activity of glutathione reductase (nmol/mg protein) in the liver of $C$. punctatus exposed to sub-lethal doses of Atrazine for 1-15 days.

\begin{tabular}{cccccc}
\hline Conc. $\mathbf{~ m g} \cdot \mathbf{L}^{-\mathbf{1}}$ & $\mathbf{1}$ & $\mathbf{5}$ & $\mathbf{E x p o s u r e ~ t i m e ~ ( d a y s )}$ & $\mathbf{1 0}$ & $\mathbf{1 5}$ \\
\hline 00 & $10.043 \pm 0.57^{\mathrm{aA}}$ & $10.050 \pm 0.04^{\mathrm{aA}}$ & $10.211 \pm 0.033^{\mathrm{aA}}$ & $10.060 \pm 0.15^{\mathrm{aA}}$ & $10.052 \pm 0.38^{\mathrm{aA}}$ \\
4.238 & $10.814 \pm 0.22^{\mathrm{aA}}$ & $10.202 \pm 0.51^{\mathrm{aA}}$ & $10.401 \pm 0.44^{\mathrm{aA}}$ & $12.162 \pm 0.61^{\mathrm{aB}}$ & $12.911 \pm 0.69^{\mathrm{aB}}$ \\
5.300 & $10.902 \pm 0.67^{\mathrm{aA}}$ & $11.013 \pm 0.60^{\mathrm{aA}}$ & $11.544 \pm 0.96^{\mathrm{aA}}$ & $13.842 \pm 0.55^{\mathrm{aB}}$ & $15.524 \pm 0.96^{\mathrm{bB}}$ \\
10.600 & $10.602 \pm 0.60^{\mathrm{aA}}$ & $11.033 \pm 0.64^{\mathrm{aA}}$ & $12.023 \pm 0.65^{\mathrm{aAA}}$ & $14.503 \pm 1.1^{\mathrm{bcC}}$ & $17.402 \pm 0.40^{\mathrm{cC}}$ \\
\hline
\end{tabular}

Note: Data are presented as mean \pm SE of 5 fishes in each group, values with different alphabet superscript differ significantly $(\mathrm{p}<0.05)$ between durations within concentration. Values with capital alphabet superscript differ significantly $(\mathrm{p}<0.05)$ between concentrations within duration.

\section{Discussion}

Fish are often used as sentinel organisms for ecotoxicological studies because they play number of roles in the trophic web, accumulate toxic substances and respond to low concentration of mutagens [34] therefore, the use of fish biomarkers as indices of the effects of pollution are of increasing importance and can permit early detection of aquatic environmental problems [35,36].

Acute toxicity data has been used to derive water quality guidelines for regulatory measures [37]. The result of the $\mathrm{LC}_{50}$ (median lethal concentration) for atrazine in the present study at $96 \mathrm{~h}$ was $42.381 \mathrm{mg} \cdot \mathrm{L}^{-1}$. The results show that the toxicity of atrazine for $C$. puctatus is both time and concentration dependent, thus, accounting for differences in $\mathrm{LC}_{10-90}$ values obtained at different concentrations and time of exposure. However, some other researchers have shown that exposure time is not significant in $\mathrm{LC}_{50}$ determinations for fish [38]. The $\mathrm{LC}_{50}$ value obtained for C. puctatus in this study is higher than that reported by Bathe et al. [39]; Neškovic et al. [11] and Hussein et al. [40], who 
reported $\mathrm{LC}_{50}$ vales of 16.0, 18.8 and $9.37 \mathrm{mgl}^{-1}$ for Lepomis macrochirus (Bluegill sunfish), Cyprinus carpio and Oreochromis niloticus, respectively, exposed to atrazine. Toxicity of chemicals to aquatic organisms has been shown to be affected by age, size and health of the species [41]. Physiological parameters like quality, temperature, $\mathrm{pH}$, dissolved oxygen and turbidity of water, amount and kind of aquatic vegetation, concentration and formulation of chemical and its exposure also greatly influence such studies [42,43]. Sprague [44] observed variability in acute toxicity even in single species and single toxicant depending on size, age and condition of the test species along with experimental factors. The estimated safe level as calculated by multiplying the $\mathrm{LC}_{50}$ with application factor (AF) varied from $4.24 \times 10^{-4}$ to 8.657 . However, the large variation in safe levels determined by different methods has resulted in controversy over its acceptability [19,45]. Kenega [46] emphasized that the major weakness in calculation of accumulation factor (AF) is its dependence on $\mathrm{LC}_{50}$. Warren [47] and Pandey et al. [48] had reported that the introduction of toxicant into an aquatic system might decrease the dissolved oxygen concentration which will impair respiration leading to asphyxiation. Fish exposed to atrazine were stressed progressively with time before death. The respiratory impairment due to the toxic effect of atrazine on the gills of $C$. punctatus is similar to the reports of Abdul-Farah et al. [41]; De Mel and Pathiratne [49]; Tilak et al. [50] and Ayoola [51] that pesticides impair respiratory organs. Death could have, therefore, occurred either by direct poisoning or indirectly by making the medium unconducive for the fish or even by both. The abnormal behavior observed during the exposure period like incessant jumping, restlessness, surface to bottom movement, vigorous jerks were similar to the observations of Hussein et al. [40]; Pandey et al. [19] and Chandra [52].

The elevated level of lipid peroxidation in the liver of $C$. punctatus in response to the exposure to atrazine as observed in the present investigation suggests that there is increased production of ROS. Increased ROS production may, thus, be associated with the metabolism of atrazine herbicide leading to the peroxidation of membrane lipids of the liver. The liver is noted as site of multiple oxidative reactions and maximal free radical generation [53-55]. Previous investigations have reported the induction of LPO by pesticides such as deltamethrin [56,57], alachlor [58], malathion [52] and butachlor [59] in fish. Lushchak et al. [60], however, did not record elevation of lipid peroxidation in the brain and liver of goldfish Crassius auratus exposed to sublethal concentration of Roundup ${ }^{\circledR}$. The different responses probably are functions of species, the time of exposure, type and concentration of stressors. The observed LPO resulting from ROS generated by the atrazine may lead to cell apoptosis. ROS and oxidative stress have been demonstrated to be triggers of apoptosis [61]. Oxidative stress may also be due to the depletion of cellular GSH content below the critical level which prevents the conjugation of xenobiotics like atrazine to GSH and thus enables them to freely combine covalently with cell proteins [62]. However, organisms are equipped with interdependent cascades of enzymes to alleviate oxidative stress and repair damaged macromolecules, produced during normal metabolism or due to exposure to xenobiotics. In this cascade, SOD and CAT are the major enzymes in eliminating ROS formed during bioactivation of xenobiotics in the hepatic tissues [63] and the induction of SOD/CAT system provides a first line of defense against ROS. SOD help to dismutase superoxide radical $\mathrm{O}_{2}^{-}$to hydrogen peroxide $\left(\mathrm{H}_{2} \mathrm{O}_{2}\right)$. The increase in CAT activities in the liver as observed in the present study may be in response to $\mathrm{H}_{2} \mathrm{O}_{2}$ produced by SOD activity since CAT is responsible for the detoxification of $\mathrm{H}_{2} \mathrm{O}_{2}$ to water. Enhancement of CAT activity was observed in Cichlid fishes from 
polluted waters [64], in mullets [65], Lepomis macrochirus [66] and Prochilobus lineatus [67] exposed to herbicides. CAT activity, however, decreased after day 7 of exposure to atrazine, although the values obtained were significantly $(\mathrm{p}<0.05)$ higher than control. Decrease in CAT activity after the 7 th day of exposure could be due to decrease in the rate of reaction as a result of the excess production of $\mathrm{H}_{2} \mathrm{O}_{2}$. The inhibition of CAT by the superoxide radical has been reported $[68,69]$. In all, the increase in LPO, CAT and SOD activities in the liver tissue as reported in the present investigation supports the hypothesis that sublethal concentrations of atrazine induce oxidative stress in C. punctatus and could be an adaptive response to protect the fish from the atrazine-induced free radical toxicity. GR activity was unchanged in the liver of $C$. punctatus following exposure to different concentrations of atrazine, except on day 10 and 15. Similar to the present observation, the hepatic GR activity in the liver of bluegill sunfish (Lepomis macrochirus) was not affected following exposure to atrazine for $96 \mathrm{~h}$ [66]. It, thus, appears that dose and exposure time affected the activity of GR in $C$. punctatus exposed to atrazine. The elevated GR observed on day 10 and 15 could be part of the protective response in the tissue which suggest that GR pathways could efficiently be used to regulate the ROS formation during the contaminated period. This compensatory response accompanied with the induction of other antioxidants (SOD and CAT) evidently helps to prevent accumulation of free radicals and their products in stressed organisms. The result of these studies evidence that the biochemical responses are dependent on stressor type, species and exposure time. Furthermore, the herbicide may lead to the occurrence of transformation products in water with a potential or actual similar or higher toxicity than their parent [70]. Metabolites/breakdown products of atrazine potentially could have affected the biochemical measurements in exposed $C$. punctatus. Thus further studies are required to determine these biochemical changes after the exposure of fish to atrazine and its transformation products.

\section{Conclusions}

The present investigation indicated that the herbicide atrazine is toxic to fish and further substantiate earlier findings that antioxidant enzymes such as SOD, CAT and GR and LPO in fish could be effectively used as biomarkers of herbicide toxicity.

\section{Acknowledgement}

The authors wish to thank TWAS-DBT for the postdoctoral fellowship (PDF) granted to C. D. Nwani and the financial assistance received. We also thank S. Shukla, Head, UNESCO Satellite Centre of Trace Elements Research, Reproductive Biology and Toxicology Laboratory, School of Studies in Zoology, Jiwaji University Gwalior (MP, India) for the facilities provided for part of the analysis.

\section{References and Notes}

1. Battaglin, W.A.; Thurman, E.M.; Kalkhoff, S.J.; Porter, S.D. Herbicides and transformation products in surface waters of the Midwestern United States. J. Am. Water Res. Assoc. 2003, 39, $743-756$. 
2. Battaglin, W.A.; Rice, C.K.; Foazio, M.J.; Salmons, S.; Barry, R.X. The occurrence of glyphosate, atrazine, and other pesticides in vernal pools and adjacent streams in Washington, DC, Maryland, Iowa and Wyoming 2005-2006. Environ. Monit. Assoc. 2008, 155, 281-307.

3. Scrubner, E.A.; Thurman, E.M.; Goolsby, D.A.; Meyer, M.T.; Battaglin, W.A.; Kolpin, D.W. Summary of significant results from studies of atrazine herbicides and their degradation products in surface water, groundwater, and precipitation in the Midwestern United States during the 1990s. In U.S. Geological Survey Scientific Investigations Report; USGS: Lawrence, KS, USA, 2005; pp. 2005-5094.

4. Orme, S.; Kegley, S. PAN Pesticide Database; Pesticide Action Network: San Francisco, CA, USA, 2004.

5. Perry, C. Source, extent and degradation of herbicides in a shallow water aquifer near Hesston, Kansas. In Water-Resources Investigation Report 91-4019; US Geological Survey: Lawrence, KA, USA, 1990.

6. Solomon, K.R.; Baker, D.B.; Richards, R.P.; Dixon, K.R.; Klaine, S. J.; La Point, T.W.; Kendall, R.J.; Weisskopf, C.P.; Giddings, J.M.; Giesy, J.P.; Hall, L.W.; Williams, W.M. Ecotoxicological risk assessment of atrazine in North American surface waters. Environ. Toxicol. Chem. 1996, 15, 31-76.

7. Selim, H. Retention and runoff losses of atrazine and metribuzin in soil. J. Environ. Qual. 2003, 32, 1058-1071.

8. De Ventura Campo, B.; de Angelis Fransceschi, D.; Marin-Morales, M.A. Mutagenic and genotoxic effects of the atrazine herbicide in Oreochromis niloticus (Perciformes, Cichlidae) detected by the micronuclei test and the comet assay. Biochem. Physiol. 2008, 90, 42-51.

9. Yoder, J.; Watson, M.; Benson, W.W. Lymphocytes chromosome analysis of agricultural workers during extensive occupational exposure to pesticides. Mutat. Res. 1973, 21, 13-17.

10. Weigand, C.; Krause, E.; Steinberg, C.; Pflugmacher, S. Toxicokinetics of atrazine in embryos of the Zebrafish (Danio rerio) Ecotoxicol. Environ. Saf. 2001, 99, 199-205.

11. Neškovic, N.K.; Elezonic, I.; Karan, V.; Poleksic, V.; Budimir, M. Acute and sub acute toxicity of atrazine to Carp (Cyprinus carpio). Ecotoxicol. Environ. Saf. 1993, 25, 173-182.

12. Lakra, W.S.; Nagpure, N.S. Genotoxicological studies in fishes: A review. Indian J. Anim. Sci. 2009, 79, 93- 98.

13. Risso-de Facerney, C.; Devaux, A.; Lafaurie, M.; Girard, J.P.; Bailly, B.; Rahmani, R.; Cadmium induces apoptosis and genotoxicity in rainbow trout hepatocytes through generation of reactive oxygen species. Aquatic Toxicol. 2001, 53, 65-76.

14. Achuba, F.I.; Osakwe, S.A. Petroleum- induced free radical toxicity in African Catfish (Clarias gariepinus). Fish Physiol. Biochem. 2003, 29, 97-103.

15. Liu, Y.; Zhang, Y.; Liu, J.; Huang, D. The role of reactive oxygen species in the herbicide acetachlor-induced DNA damage on Bufo-raddei tadpole liver. Aquatic Toxicol. 2006, 78, 21-26.

16. Monteiro, D.A. ; Almeida, J.A.; Rantin, F.T.; Kalinin, A.L. Oxidative stress biomarkers in the freshwater characid fish Brycon cephalus, exposed to organophosphon insecticide Folisuper 600 (Methyl parathion). Comp. Biochem. Physiol. 2006, 143, 141-149. 
17. Peña-Llopis, S.; Ferrando, M.D.; Peña, J.B. Fish tolerance to organophosphate- induced oxidative stress is dependent on the glutathione metabolism and enhanced by $\mathrm{N}$ - acetylcysteine. Aquatic Toxicol. 2003, 65, 337-360.

18. Banudevi, S.; Krishnamoorthy, G.; Venkatataman, P.; Vignesh, C.; Aruldhas, M.M.; Arunakaran, J. Role of $\alpha$-tocopherol on antioxidant status in liver, lung and kidney of PCP exposed male albino rats. Food Chem. Toxicol. 2006, 44, 2040-2046.

19. Pandey, S.; Kumar, R.; Sharma, S.; Nagpure, N.S.; Sirivastava, S.K.; Verma, M.S. Acute toxicity bioassays of mercuric chloride and malathion on air breathing fish Channa punctatus (Bloch). Ecotoxicol. Environ. Saf. 2005, 61, 114-120.

20. Organization for Economic Cooperation and Development (OECD). Guideline for the Testing of Chemicals: Fish, Acute Toxicity Test, Document 203; OECD: Paris, France, 1992.

21. Pluta, H.J. Toxicity of several xenobiotics and waste water effluents measured with a new fish early life stage test. Ger. J. Applied Zool. 1989, 76, 195-220.

22. Finney, D.T. Probit Analysis; Cambridge University Press: Cambridge, UK, 1971.

23. Sharma, S.K.; Krishnamurthy, C.R. Production of lipid peroxidation of brain. J. Neurochem.1968, 15, 147-149.

24. Misra, H.P.; Fridovich, I. The role of superoxide anion in the autoxidation of epinephrine and a simple assay for superoxide dismutase. J. Biol. Chem. 1972, 247, 3170-3175.

25. Clairborne, A. Catalase activity. In Handbook of Methods for Oxygen Radical Research; Greewald, A.R., Ed.; CRC Press: Boca Raton, FL, USA, 1995; pp. 237-242.

26. Massey, V.; Williams, C.H. On the reaction mechanism of yeast glutathione reductase. J. Biol. Chem. 1965, 240, 4470-4481.

27. Lowry, O.H.; Rosebrough, N.J.; Farr, A.L.; Randall, R.J. Protein measurement with folin phenol reagent. J. Biol. Chem. 1951, 193, 265-275.

28. Sprague, J.B. Measurement of pollutant toxicity to fish I. Bioassay methods for acute toxicity. Water Res. 1971, 3, 793-821.

29. Committee on Water Quality Criteria (CWQC). A Report of the Committee on Water Quality Research Series, EPA-R3-73-003, US Environmental Protection Agency Report; CWQC: Cincinnati, OH, USA, 1972.

30. NAS/NAE (1973) Water Quality Criteria, EPA-R3-033; US Government Printing Office: Washington, DC, USA, 1973.

31. IJC. New and Revised Great Lakes Water Quality Objectives. Great Lake Basin, Windsor; IJC: Ottawa, ON, Canada, 1977.

32. CCREM. Canadian Water Quality Guidelines; Canadian Council of Resources and Environmental Ministry, Inland Waters Directorate, Environment Canada: Ottawa, ON, Canada, 1991.

33. Hart, W.B.; Weston, R.F.; Demann, J.G. An apparatus for Oxygenating test solution in which fish are used as test animals for evaluating toxicity. Trans. Am. Fish Soc. 1948, 75, 288.

34. Cavas, T.; Ergene-Gözükara, S. Micronucleus test in fish cells, a bioassay for in situ monitoring of genotoxic pollution in the marine environment. Environ. Mol. Mutagen. 2005, 46, 64-70.

35. Lopez-Barea, J. Biomarkers to detect environmental pollution. Toxicol. Lett. 1996, 88, 79. 
36. Van Der Oost, R.; Beyer, J.; Vermeulen, N.P.E. Fish bioaccumulation and biomarkers in environmental risk assessment: a review. Environ. Toxicol. Pharm. 2003, 13, 57-149.

37. Sunderam, R.I.M.; Thompson, G.B.; Chapman, J.C.; Cheng, D.M.H. Acute and chronic toxicity of endosulfan to two Australian Cladocerans and their applicability in deriving water quality criteria. Arch. Environ. Cont. Toxicol. 1994, 27, 541-545.

38. Lakota, S.; Razska, A.; Utracki, T.; Chmiel, Z. Side effect of deltamethrin and cypermthrin in the environment of water biocenoses. Organika 1989, 71, 71-77.

39. Bathe, R.; Ullmann, L.; Sachsse, K. Determination of pesticide toxicity to fish. Berlin-Dahlem 1973, 37, 241-246.

40. Hussein, S.Y.; El-Nasser, M.A.; Ahmed, S.M. Comparative studies on the effects of herbicide Atrazine on freshwater fish Oreochromis niloticus and Chrysichthys auratus at Assiut Egypt. Bull. Environ. Contam. Toxicol. 1996, 57, 503-510.

41. Abdul-Farah, M.; Ateeq, B.; Ali, M.N.; Ahmad, W. Studies on lethal concentrations and toxicity stress of some xenobiotics on aquatic organisms. Chemosphere 2004, 55, 257-265.

42. Gupta, P.K.; Khangant, B.S.; Durve, V.S. The temperature dependence of the acute toxicity of copper to freshwater pond snail, Viviparus bengalensis L. Hydrobiologia 1981, 83, 461-464.

43. Young, R.A. Biomedical discovery with DNA arrays. Cell 2000, 102, 9-15.

44. Sprague, J.B. Lethal concentrations of copper and Zinc for young Atlantic salmon. J. Fish Res. Board Can. 1969, 21, 17.

45. Buikema, J.R.; Naider-Lehner, A.L.; Cairns, J.R. Biological monitoring: Part IV. Toxicity testing. Environ. Mol. Mutagen. 1982, 33, 239-262.

46. Kenega, E.F. Aquatic test organism and methods useful for assessment of chronic toxicity of chemicals. In Analyzing the Hazard Evaluation Process; Dickson, K.L., Maki, A.W., Cairns, J. Jr, Eds.; American Fisheries Society: Washington, DC, USA, 1979.

47. Warren, C.E. Biology and Water Pollution; W.B. Saunders Company: Philadelphia, PA, USA, 1997.

48. Pandey, R.K.; Singh, R.N.; Singh, S.; Singh, N.N.; Das, V.K. Acute toxicity bioassay of dimethoate on freshwater air breathing catfish Heteropneustus fossilis (Bloch). J. Environ. Biol. 2009, 30, 437-440.

49. De Mel, G.W.J.L.M.V.T.M.; Pathiratne, A. Toxicity assessment of insecticides commonly used in rice pest management to the fry of common carp, Cyprinus carpio, a food fish culturable in rice fields. J. Appl. Icthyol. 2005, 21, 146-150.

50. Tilak, K.S.; Veeraiah, K.; Bhaskara, P.; Butchiram, M.S. Toxicity studies of Butachlor to the freshwater fish Channa punctata (Bloch). J. Environ. Biol. 2007, 28, 285-487.

51. Ayoola, S.O. Toxicity of glyphosate herbicide on Nile tilapia (Oreochromis niloticus) juveline. African J. Agric. Res. 2008, 3, 825-834.

52. Chandra, S. Toxic effect of Malathion on acetylcholinesterase activity of liver, brain and gills of freshwater catfish Heteropneutes fossilis. Environ. Conserv. 2008, 9, 45-52.

53. Gül, S.; Belge-Kurutas, E.; Yildiz, E.; Sahan, A.; Doran, F. Pollution correlated modifications of liver antioxidant systems and histopathology of fish. (Cyprinidae) living in Seyhan Dan Lake. Turkey Environ. Int. 2004, 30, 605-609. 
54. Avci, A.; Kacmaz, M.; Durak, I. Peroxidation in muscle and liver tissues from fish in a contaminated river due to petroleum refinery industry. Ecotoxicol. Environ. Saf. 2005, 6, 101-105.

55. Atli, G.; Alptekin, O.; Tukel, S.; Canlin, M. Response of catalase activity to $\mathrm{Ag}^{+}, \mathrm{Cd}^{+}, \mathrm{Cr}^{6+}, \mathrm{Cu}^{2+}$ and $\mathrm{Zn}^{2+}$ in five tissues of fresh water fish Oreochromis niloticus. Comp. Biochem. Physiol. C 2006, 143, 218-224.

56. Atif, F.; Parvez, S.; Pandey, S.; Ali, M.; Kaur, M.; Rehman, H.; Khan, H. A.; Raisuddin, S. Modulatory effect of Cadmium exposure on Deltamethrin- induced oxidative stress in Channa punctatus. Arch. Environ. Contam. Toxicol. 2005, 49, 371-377.

57. Şimşek-Köprücü, S.; Yanar, E.; Seker, E. Effects of Deltamethrin on antioxidant status and oxidative stress biomarkers in freshwater mussel Unio elongatulus euchres. Bull. Environ. Contam. Toxicol. 2008, 81, 253-257.

58. Peebua, L.P.; Kosiyachinda, P.; Pokethitiyook, P.; Kruatrachue, M. Evaluation of alachlor herbicide impacts on Nile Tilapia (Oreochromis niloticus) using biochemical biomarkers. Bull. Environ. Contam. Toxicol. 2007, 78, 138-141.

59. Farombi, E.O.; Ajimoko, Y.R.; Adelowo, O.A. Effect of butachlor on antioxidant enzyme status and lipid peroxidation in freshwater African catfish (Clarias gariepinus). Int. J. Environ. Res. Public. Health 2008, 5, 423-427.

60. Lushchak, O.V.; Kubrak, O.I.; Storey, M.J.; Storey, B.K.; Lushchak, I.V. Low toxic herbicide roundup induces mild oxidative stress in gold fish. Chemosphere 2009, 76, 932-937.

61. Shen, H.M.; Liu, Z.G. JNK signaling pathway is a key modification in cell death mediated by reactive oxygen and nitrogen species. Free Radic Biol. Med. 2006, 40, 928-939.

62. Yamano, T.; Morita, S. Effects of pesticides on isolated hepatocytes, mitochondria and microsomes 11. Arch. Environ. Contam. Toxicol. 1995, 28, 1-7.

63. Sk, H.U.; Bhattacharya, S. Prevention of cadmium induced lipid peroxidation, depletion of some antioxidantive enzymes and glutathione by series of organoselenocyanates. Environ. Toxicol. Pharmacol. 2006, 22, 298-308.

64. Filho, D.W.; Torresl, M.A.; Tribessl, T.B.; Pedresosa, R.C.; Soares, C.H.L. Influence of season and pollution on the antioxidant defenses on the Cichlid fish acara Geophagus brasiliensis. Braz. J. Med. Biol. Res. 2001, 34, 719-726.

65. Karakoc, F.T.; Hewer, A.; Philips, D.H.; Gaiñes, A.F.; Yuregir, G. Biomarkers of marine pollution observed in species of mullet living in two Eastern Mediterranean harbours. Biomarkers. 1997, 2, 303-309.

66. Elia, A.C.; Waller, W.T.; Norton, S.J. Biochemical responses of Bluegill sunfish (Lepomis macrochirus, Rafinesque) to atrazine induced oxidative stress. Bull. Environ. Contam. Toxicol, 2002, 68, 809-816.

67. Langiano, V.C.; Martinez, C.B.R. Toxicity and effects of a glyphosate-based herbicide on the Neotropical fish Prochilodus lineatus. Comp. Biochem. Physiol. C 2008, 147, 222-231.

68. Kono, I.; Fridonch, Y. Superoxide radical inhibits catalase. J. Biol. Chem. 1982, 257, 5751. 
69. Saravanan, R.; Revathi, K.; Murthy, B. Lambda cyhalothrin induced alterations in antioxidant enzyme status of various tissues in freshwater catfish Clarias batrachus. Asian J. Microbiol. Biotech. Environ. Sci. 2008, 10, 341-349.

70. Tchounwou, P.B.; Wilson, B.; Ishaque, A.; Ransome, R.; Huang, M.J.; Leszczynski, J. Toxicity assessment of atrazine and related triazine compounds in the microtox assay and computational modeling for their structure-activity relationship. Int. J. Mol. Sci. 2000, 1, 63-74.

(C) 2010 by the authors; licensee MDPI, Basel, Switzerland. This article is an Open Access article distributed under the terms and conditions of the Creative Commons Attribution license (http://creativecommons.org/licenses/by/3.0/). 